九州大学学術情報リポジトリ

Kyushu University Institutional Repository

Asteralobia Gall Midges (Diptera:

Cecidomyiidae) on Aster Species (Asteraceae) in Japan and the Russian Far East

Tokuda, Makoto

Yukawa, Junichi

Kuzntsov, Victor $\mathrm{N}$

Kozhevnikov, Andrey E

https://doi.org/10.5109/2667

出版情報: ESAKIA. 43，pp.1-10，2003-03-31. Entomological Laboratory, Faculty of Agriculture， Kyushu University

バージョン：

権利関係 : 


\title{
Asteralobia Gall Midges (Diptera: Cecidomyiidae) on Aster Species (Asteraceae) in Japan and the Russian $\mathbb{F a r} \mathbb{E a s t}^{*}$
}

\author{
Makoto TOKUDA
}

Entomological Laboratory, Graduate School of Bioresource and Bioenvironmental Sciences, Kyushu University, Fukuoka, 812-8581 Japan

\section{Junichi YUKAWA}

Entomological Laboratory, Faculty of Agriculture, Kyushu University, Fukuoka, 812-8581 Japan

\author{
Victor N. KUZNETSOV and Amdrey E. KOZHEVNIKOV \\ Institute of Biology and Soil Science, Far East Branch of Russian Academy of Science, \\ Vladivostok, 690022 Russia
}

\begin{abstract}
Full-grown larvae of Asteralobia doellingeriae and Asteralobia asteris were redescribed. An unidentified gall midge forming drop-shaped flower galls on Aster scaber in Japan was identified as A. doellingeriae, which had been known only from the Russian Far East but was newly recorded from Japan. Gall midges causing flower galls on Aster ageratoides subsp. ovatus and Aster glehni var. hondoensis in Japan were identified as Asteralobia species.
\end{abstract}

Key words: Asteralobia doellingeriae, Asteralobia asteris, Aster scaber, flower gall, identification, redescription.

\section{Introduction}

Phylogenetic relationships between certain plant taxa and associated herbivores have been paid special attention by many biologists in order to clarify the coevolutionary and speciation processes of the herbivores (e.g. Scheffer \& Wiegmann, 2000; Cook et al., 2002).

The family Asteraceae and associated herbivores are one of the most suitable materials for such evolutionary studies, because Asteraceae is considered to be a monophyletic

*Contribution from the Entomological Laboratory, Faculty of Agriculture, Kyushu University, Fukuoka (Ser. 5, No. 92). 
group that has recently radiated throughout the world (e.g. Judd et al., 1999; Wildner et al., 1999; Panero \& Funk, 2002).

In the case of gall-forming Cecidomyiidae, for example, about 250 species of the genus Rhopalomyia are associated mostly with the genus Artemisia and its related genera belonging to the tribe Anthemideae of Asteraceae (e.g. Skuhravá, 1986; Gagné, 1994; Yukawa \& Masuda, 1996; R. J. Gagné, in press, A Catalog of the Cecidomyiidae (Diptera) of the World. Proc. Entomol. Soc. Wash.), nine species of the genus Asteromyia are associated with the tribe Asterae in the Nearctic Region (e.g. Gagné, 1968; Gagné, 1969), and three species of the genus Asteralobia are associated with several genera of Asteraceae such as Aster, Cacaria, Senecio, and Solidago in the Russian Far East (Kovalev, 1964). Among them, we refer to the Asteralobia gall midges on Aster spp. in this study.

We intend to (1) redescribe the full-grown larvae of two Russian species of Asteralobia, A. doellingeriae and A. asteris; (2) clarify the taxonomic status of some gall midges associated with Aster spp. in Japan; and (3) supplement the host and distributional information of Asteralobia gall midges in Japan and the Russian Far East. All results obtained from this study will contribute to future coevolutionary studies of Asteraceae and associated gall midges in the eastern Holarctic Region.

\section{Materials and Methods}

\section{Scientific names of host plants}

Scientific names of some plant species are differently used in Japan and Russia even though these plants are commonly distributed in both countries. For example, Aster scaber Thunb. that has been used in Japan (e.g. Kitamura, 1981; Hotta et al., 1989) is called Doellingeria scabra (Thunb.) Nees. in Russia (e.g. Kovalev, 1964; Charkevicz, 1992; Kozhevnikov \& Probatova, 2002). In order to avoid confusion in host plant nomenclature, the scientific names of all plant species appearing in this study consistently follow Kitamura (1981).

\section{General information about midge galls on Aster species in Japan and the Russian Far East}

According to Yukawa \& Masuda (1996), 13 sorts of cecidomyiid gall have been recorded from Japan on four Aster species, A. ageratoides Turcz. subsp. leiophyllus (Franch. et Savat.) Kitam. var. ovalifolius Kitam., A. ageratoides subsp. ovatus (Franch. et Savat.) Kitam., A. glehnii Fr. Schm. var. hondoensis Kitam., A. scaber, and $A$. tataricus L. fil. Among them, four sorts of gall are caused by Lasioptera species and one by Dasineura, while the gall midges responsible for eight other galls have not yet 
Table 1. Collection records of Asteralobia galls on Aster spp. in Primorsky Territory (2002).

\begin{tabular}{|c|c|c|c|c|c|}
\hline Date & Locality & Location & $\begin{array}{l}\text { Altitude } \\
(\mathrm{m})\end{array}$ & Host & Gall $^{*}$ \\
\hline \multirow[t]{2}{*}{ Sept. 13} & Shkotovo & $\mathrm{N} 43^{\circ} 17^{\prime}, \mathrm{E} 132^{\circ} 21^{\prime}$ & 0 & A. scaber & $D \& S$ \\
\hline & Smolyaninovo & $\mathrm{N} 43^{\circ} 11^{\prime}$, E $132^{\circ} 41^{\prime}$ & 20 & $\begin{array}{l}\text { A. scaber } \\
\text { A. tataricus }\end{array}$ & $\begin{array}{c}D \& S \\
S\end{array}$ \\
\hline \multirow[t]{2}{*}{ Sept. 14} & Mt. Litovka & $\mathrm{N} 43^{\circ} 06^{\prime}, \mathrm{E} 132^{\circ} 48^{\prime}$ & $425-1250$ & A. scaber & $\mathrm{D}$ \\
\hline & Mt. Sestra & $\mathrm{N} 42^{\circ} 49^{\prime}$, E $133^{\circ} 00^{\prime}$ & 105 & A. scaber & $D \& S$ \\
\hline Sept. 15 & Bay Tryohozerye & $\mathrm{N} 42^{\circ} 45^{\prime}$, E $133^{\circ} 13^{\prime}$ & 30 & A. scaber & $D \& S$ \\
\hline Sept. 18 & Dukhovskoye & $\mathrm{N} 44^{\circ} 36^{\prime}, \mathrm{E} 131^{\circ} 24^{\prime}$ & 290 & A. scaber & $\mathrm{S}$ \\
\hline
\end{tabular}

"Abbreviations of gall are as follows: D: Drop-shaped flower galls caused by Asteralobia doellingeriae; S: Subglobular flower galls caused by Asteralobia asteris.

been identified.

In the Russian Far East, Kovalev (1964) described two Aster-associated gall midges, Asteralobia doellingeriae Kovalev and Asteralobia asteris Kovalev. The former forms drop-shaped flower galls on $A$. scaber and the latter is responsible for subglobular flower galls on A. scaber and A. tataricus.

\section{Collection of galls and preservation of gall midge specimens}

In this study, we examined $75 \%$ ethanol stored specimens of cecidomyiid larvae that had been collected from flower galls on Aster spp. by JY and his colleagues from Honshu, Japan in the 1970s and 1980s.

In addition, MT, VNK, and AEK searched for flower galls caused by Asteralobia gall midges on Aster spp. in Primorsky Territory of the Russian Far East in September, 2002. Detailed collection data in the Russian Far East is shown in Table 1. All galls collected in the Russian Far East were dissected under a binocular microscope and the full-grown larvae were picked out of the galls and divided into two groups. One group was stored in $75 \%$ ethanol to make slide-mounted specimens for morphological studies and another in $99.5 \%$ acetone for future DNA analysis.

\section{Morphological studies and terminology}

Some of the ethanol-stored specimens were mounted on slides for microscopic study in Canada balsam using the techniques outlined in Gagné (1989). Drawings were made with the aid of a camera lucida.

Larval morphological terminology follows usage in Möhn (1955; originally written in German) that were translated into English in Yukawa (1971). 


\section{Resullts and Remarks}

Redescription of Asteralobia gall midges on Aster spp.

\section{Asteralobia doellingeriae Kovalev}

(Fig. 1A-C)

Asteralobia doellingeriae Kovalev, 1964: 422.

Male: See Kovalev (1964).

Female: See Kovalev (1964).

Full-grown larva: Yellow in body color. Body length 2.6 to $2.9 \mathrm{~mm}$. Second antennal segment short, conical, about $18 \mu \mathrm{m}, 2.5$ times as long as basal width; cervical papillae without seta. Number and position of spiracles normal; 6 dorsal papillae present on thoracic and first to seventh abdominal segments, each with a seta; 2 dorsal papillae present between spiracles of eighth abdominal segment, each with a seta; usually 3 pleural papillae present each side, each with a seta; 8 terminal papillae present, 2 of them each with a little pigmented large conical seta, and other 6 papillae each with a setiform seta.

Sternal spatula about $160 \mu \mathrm{m}$ in length, distally emarginated, forming a pair of triangular lobes; 3 inner lateral papillae present, 2 of them each with a seta on all thoracic segments, 3 outer lateral papillae present, 2 of them with a seta on all thoracic segments; sternal papillae without seta on all thoracic segments; inner pleural papilla without seta on prothoracic segment and with a seta on meso- and metathoracic segments; 4 anterior ventral papillae without seta; 2 posterior ventral papillae each with a seta; 4 ventral papillae of eighth abdominal segment each without seta; 4 anal papillae each without seta. Anal split linear.

Pupa: See Kovalev (1964).

Host plant: A. scaber.

Specimens examined: 6 full-grown larvae (on slides), galls collected from Mt. Iouzen, Kanazawa City, Ishikawa Pref., Honshu, Japan, J. Yukawa leg.; 6 full-grown larvae (on slides), galls collected from Shkotovo, Primorsky Territory, the Russian Far East, Sep. 13, 2002, M. Tokuda, V. N. Kuznetsov \& A. E. Kozhevnikov leg.

Distribution: The Russian Far East, Japan (Honshu): mew rec.

Remarks: Asteralobia doellingeriae is the type species of the genus. The larva exhibits typical morphological features of the genus Schizomyia such as the existence of three inner and three outer lateral papillae and eight terminal papillae. Therefore, future detailed examination of adult and pupal morphological studies will synonymize Asteralobia with Schizomyia although Kovalev (1964) distinguish Asteralobia from 

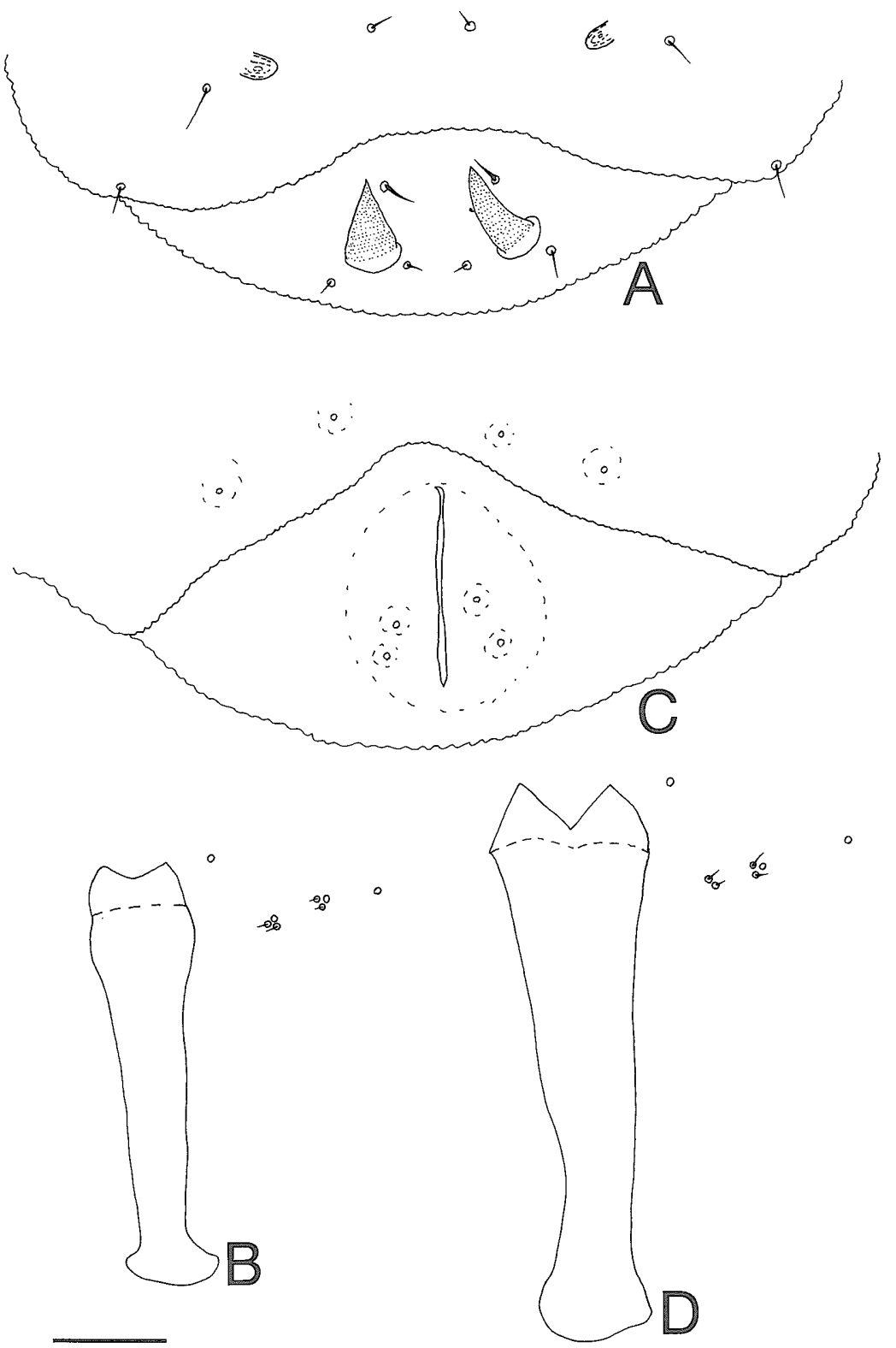

Fig. 1. A-C: Asteralobia doellingeriae, A: eighth and ninth abdominal segments of full-grown larva in dorsal view; B: sternal spatula of full-grown larva and associated papillae; $\mathrm{C}$ : eighth and ninth abdominal segments of full-grown larva in ventral view; D: Asteralobia asteris, sternal spatula of full-grown larva and associated papillae. Scale: $0.10 \mathrm{~mm}$. 
Schizomy only by shallowly constricted male flagellomeres.

Lasioptera gibaushi Shinji, 1939 has been considered to produce drop-shaped galls on flowers of Aster scaber (= Doellingeria scabra) in Japan (e.g. Shinji, 1939; Shinji, 1944; Skuhravá, 1986; Yukawa \& Masuda, 1996). However, the full-grown larvae inhabiting the galls do not have characteristics of the genus Lasioptera, but are morphologically very similar to those of $A$. doellingeriae. In addition, we compared in 2002 the structure of galls caused by $A$. doellingeriae in the Russian Far East with the drop-shaped galls in Japan and reached the conclusion that the two sorts of gall are structurally identical. Therefore, we identified the midge larvae that are responsible for the drop-shaped galls in Japan not as L. gibaushi but as A. doellingeriae.

Although L. gibaushi was inadequately described in Shinji (1939), it is apparently not identical with $A$. doellingeriae because, for example, the former has 21 antennal segments according to Shinji (1944). Therefore, it is highly probable that in the original description, Shinji (1939) recorded the gall caused by A. doellingeriae erroneously as that by L. gibaushi. Because he did not refer to type or any other specimens examined, it is now difficult to determine what sort of gall is produced by the gall midge with the name of L. gibaushi.

\section{Asteralobia asteris Kovalev}

(Figs. 2D \& 3)

\section{Asteralobia asteris Kovalev, 1964: 425.}

Male: See Kovalev (1964).

Female: See Kovalev (1964).

Full-grown larva: Yellow in body color. Body length about $3.0 \mathrm{~mm}$. Second antennal segment short, conical, about $16 \mu \mathrm{m}, 2.5$ times as long as basal width; cervical papillae without seta. Number and position of spiracles normal; 6 dorsal papillae present, each with a seta; eighth abdominal segment with 2 dorsal papillae, each of which is situated on a low hemispherical swelling, each papilla with a seta; an additional swollen area present between dorsal papillae on eighth abdominal segment as in Fig. 2A; 3 pleural papillae present on each side, each with a seta; 4 terminal papillae visible, 2 of them each with a little pigmented large conical seta, other 2 each with a setiform seta, remaining 4 inconspicuous.

Sternal spatula $260 \mu \mathrm{m}$ in length, distally incised by a U-shaped emargination, forming a pair of triangular lobes; 2 inner lateral papillae present, each with a seta on all thoracic segments, 3 outer lateral papillae present, two of them with a seta on all thoracic segments; sternal papillae without seta on all thoracic segments; inner pleural 
papillae without seta on prothorax and with a seta on meso- and metathorax; 4 anterior ventral papillae without seta; 2 posterior ventral papillae each with a seta; 4 ventral papillae of eighth abdominal segment without seta; 4 anal papillae without seta. Anal split not linear, but wavy.

Pupa: See Kovalev (1964).

Host plants: A. scaber and A. tataricus.

Specimens examined: [Host: A. tataricus] 4 full-grown larvae (on slides), galls collected from Smolyaninovo, Primorsky Territory, the Russian Far East, Sep. 13, 2002, M. Tokuda, V. N. Kuznetsov \& A. E. Kozhevnikov leg.; [Host: A. scaber] 6 fullgrown larvae (on slides), galls collected from Smolyaninovo, Primorsky Territory, the Russian Far East, Sep. 13, 2002, M. Tokuda, V. N. Kuznetsov \& A. E. Kozhevnikov leg.

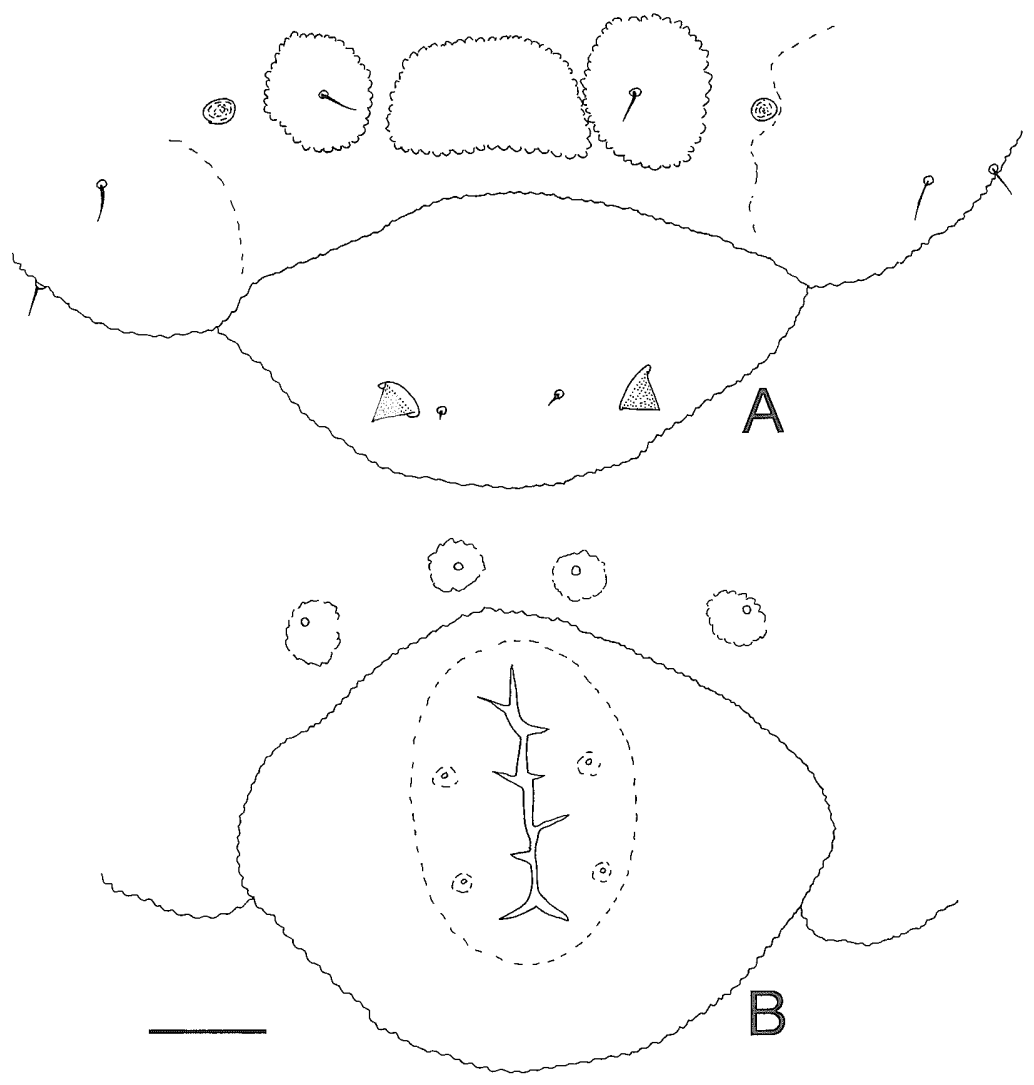

Fig. 2. Asteralobia asteris, A: eighth and ninth abdominal segments of full-grown larva in dorsal view; B: eighth and ninth abdominal segments of full-grown larva in ventral view. Scale: $0.10 \mathrm{~mm}$. 
Table 2. List of gall midges associated with Aster spp. in Japan (modified from Yukawa \& Masuda, 1996 based on the results of this study).

\begin{tabular}{lccc}
\hline Host plant species & Galled organ & Shape of gall & Gall midge species $*$ \\
\hline $\begin{array}{c}\text { Aster ageratoides } \\
\text { subsup. leiophyllus } \\
\text { var. ovalifolius }\end{array}$ & Bud & Cluster-shaped gall & Unidentified \\
Aster ageratoides & & & \\
subsp. ovatus & Bud & Cluster-shaped gall & Unidentified \\
& Flower & Drop-shaped gall & Asteralobia sp. \\
Aster glehnii var. & Stem & Irregular swelling & Unidentified \\
hondoensis & Leaf & Pit gall & Unidentified \\
& Flower & Subglobular gall & Asteralobia sp. \\
& Stem & Irregular swelling & Lasioptera astericola \\
Aster scaber & Stem \& leaf & Cluster-shaped gall & Dasineura asteriae \\
& Leaf edge & Subglobular gall & Unidentified \\
& Leaf & Conical gall & Lasioptera sp. \\
& Flower & Subglobular gall & Unidentified \\
& Flower & Drop-shaped gall & Asteralobia doellingeriae \\
& Stem & Spindle-shaped gall & Lasioptera euphobiae
\end{tabular}

※Taxonomic status of gall midges indicated by gothic letters is newly proposed in this study.

Distribution: The Russian Far East.

Remarks: The larva of $A$. asteris is distinguishable from that of $A$. doellingeriae by the number of inner lateral papillae and terminal papillae, the existence of swollen portion on dorsal surface of eighth abdominal segment, and the shape of anal split.

The galls caused by $A$. asteris are similar to those produced by an unidentified gall midge on flowers of $A$. scaber in Japan (Yukawa \& Masuda, 1996). We could not examine specimens of the unidentified gall midges, but the gall shapes of both species indicated that the Japanese gall midge might be identical with $A$. asteris or its close relative.

\section{Other gall midges causing flower galls on Aster species in Japan}

In this study, we also examined morphological features of larval specimens collected from flower galls on A. ageratoides subsp. ovatus and A. glehni var. hondoensis in Japan. As a result, the gall midges on the two plant species could not be clearly distinguished from A. asteris. Although they are considered to be identical with or closely related to $A$. asteris, further comparative studies of adult and pupal morphology are needed to identify these species. Thus, in this study, we tentatively deal with these 
gall midges as unidentified species of the genus Asteralobia. As a consequence, the taxonomic status of Aster associated gall midges in Japan is revised as in Table 2.

Specimens examined: [Host: A. ageratoides subsp. ovatus] 4 full-grown larvae (on slides), galls collected from Mt. Iouzen, Kanazawa City, Ishikawa Pref., Honshu, Japan, Oct. 17, 1978, H. Ikenaga leg.; [Host: A. glehni var. hondoensis] 4 full-grown larvae (on slides), galls collected from Maruyama, Ojiya City, Niigata Pref., Honshu, Japan, Oct. 12, 1981, K. Yamagishi leg.

\section{Asteralobia on other Asteraceae than the genus Aster in Japan}

In Japan, subglobular flower galls similar to those by A. asteris are known to occur also on such asteraceous genera as Eupatrium, Senecio, and Solidago (Yukawa \& Masuda, 1996). According to preliminary DNA analysis of these gall midges (M. Tokuda \& J. Yukawa, unpublished data), they are rather closely related to A. asteris. Future detailed and comprehensive studies will reveal the taxonomic status and evolutionary processes of these species.

\section{Acknowledgments}

We wish to express our thanks to Dr. K. Yamagishi (Meijo University, Japan) and Mr. H. Ikenaga (National Food Research Institute, Japan) for offering materials. One of us, MT, also thanks Assoc. Prof. O. Tadauchi, Assist. Prof. S. Kamitani, and Mr. D. Yamaguchi (Entomological Laboratory, Kyushu University, Japan) for their support.

\section{References}

Charkevicz, S. S., 1992. Vascular Plants of the Soviet Far East vol. 6 Asteraceae (Compositae). 427pp. Nauka, Sankt Peterburg. (In Russian.)

Cook, J. M., A. Rokas, M. Pagel \& G. N. Stone, 2002. Evolutionary shifts between host oak species and host plant organs in Andricus gallwasps. Evolution, 56: 18211830.

Gagné, R. J., 1968. A taxonomic revision of the genus Asteromyia (Diptera: Cecidomyiidae). Misc. Publ. Entomol. Soc. Am., 6: 1-40.

Gagné, R. J., 1969. A tribal and generic revision of the Nearctic Lasiopteridi (Diptera: Cecidomyiidae). Ann. Entomol. Soc. Am., 62: 1348-1364.

Gagné, R. J., 1994. The Gall Midges of the Nearctic Region. 352pp. Cornel University Press, Ithaca \& London.

Hotta, M., K. Ogata, A. Nitta, K. Hoshikawa, M. Yanagi \& K. Yamazaki, 1989. Useful Plants of the World. 1499pp. Heibonsha, Tokyo. (In Japanese.) 
Judd, W. S., C. S. Campbell, E. A. Kellogg \& P. F. Stevens, 1999. Plant Systematics a Phylogenetic Approach. 464pp. Sinauer Associates, Inc., Sunderland.

Kitamura, S., 1981. Compositae (Asteraceae). pp. 156-235, pls., In Satake, Y., H. Hara, S. Watari and T. Tominari (eds.), Wild Flowers of Japan Herbaceous Plants (Including Dwarf Subshrubs). Heibonsha, Tokyo. (In Japanese.)

Kozhevnikov, A. E. \& N. S. Probatova, 2002. Flora of the Russian Far East Alphabetical Indexes to the "Vascular plants of the Soviet Far East" vols. 1-8. (19851996). 178pp. Dalnauka, Vladivostok. (In Russian.)

Kovalev, O. V., 1964. Review on gall-midges (Diptera, Itonididae) from the extreme south of far east. I. The supertribe Asphondyliidi. Entomol. Obozr., 43: 418-446. (In Russian with English translation published in Entomological Review, 43: 215-228.)

Möhn, E., 1955. Beiträge zur Systematik der Larven der Itonididae (= Cecidomyiidae, Diptera). 1. Teil: Porricondylinae und Itonidinae Mitteleuropas. Zoologica, 105: 1247, pls. (In German.)

Panero, J. L. \& V. A. Funk, 2002. Toward a phylogenetic subfamilial classification for the Compositae (Asteraceae). Proc. Biol. Soc. Wash., 115: 909-922.

Scheffer, S. J. \& B. M. Wiegmann, 2000. Molecular phylogenetics of the holly leafminers (Diptera: Agromyzidae: Phytomyza): species limits, speciation, and dietary specialization. Mol. Phylogenet. Evol., 17: 244-255.

Shinji, O., 1939. 4 new species of Cecidomyiidae from north-eastern Japan. Volumen Jubilare pro Professore Sadao Yoshida, 2: 561-569, pls. (In Japanese.)

Shinji, O., 1944. [Galls and Gall Making Insects]. 580pp., pls. Shunyôdô, Tokyo. (In Japanese.)

Skuhravá, M., 1986. Family Cecidomyiidae. pp. 72-297, In Soós, A. \& L. Papp (eds.), Catalogue of Palaearctic Diptera: Sciaridae - Cecidomyiidae. Vol. 4. Akadémiai Kiadó, Budapest.

Wildner, G. F., J. Schlitter \& T. Stutzel, 1999. Phylogenetic analysis of the C-Terminal sequence of rbcL. Pl. Biol., 1: 656-664.

Yukawa, J., 1971. A revision of the Japanese gall midges (Diptera: Cecidomyiidae). Mem.Fac.Agr.Kagoshima Univ., 8: 1-203.

Yukawa, J. \& H. Masuda, 1996. Insect and Mite Galls of Japan in Colors. 826pp. Zenkoku Nôson Kyôiku Kyôkai,Tokyo. (In Japanese with English explanations for color plates.) 